\title{
Swarming in honey bees (Apis mellifera) and Varroa destructor population development in Sweden
}

\author{
Ingemar FRIES $^{a *}$, Henrik HANSEN $^{\mathrm{b}}$, Anton IMDORF ${ }^{\mathrm{c}}$, Peter ROSENKRANZ ${ }^{\mathrm{d}}$ \\ a Department of Entomology, Swedish University of Agricultural Sciences, Box 7044, 75007 Uppsala, Sweden \\ ${ }^{\mathrm{b}}$ Research Group Entomology, Danish Institute of Agricultural Sciences, Research Centre Flakkebjerg, \\ 4200 Slagelse, Denmark \\ c Swiss Apicultural Institute FAM, Liebefeld, 3003 Bern, Switzerland \\ d State Institute of Apiculture, University of Hohenheim, 70593 Stuttgart, Germany
}

(Received 13 August 2002; revised 26 November 2002; accepted 11 January 2003)

\begin{abstract}
In a honey bee population of 150 colonies, the development of an introduced Varroa destructor mite population was monitored in swarming and non-swarming colonies for two years in a Nordic climate. The results demonstrated a reduced mite population as a result of swarming only for the first swarm season studied. In the second swarm season, there were much higher mite levels (based on debris counts of mites) and fewer colonies swarmed, but there was no significant difference in infestation levels of adult bees in the fall between swarming and non-swarming colonies. This result was interpreted as an effect of host-parasite interactions, where the detrimental influence from the infestation prohibited growth (and swarming) in some colonies, but allowed better mite reproduction opportunities (and swarming) in others. Surprisingly, the mite infestation levels of swarms in the late fall were not significantly different from those of swarming colonies the same year, indicating that swarm survival may be almost as much affected by $V$. destructor, as intact, swarming colonies. No horizontal mite transfer through robbing was observed. The results suggest that, horizontal mite transfer may not be as important in a Nordic climate where many bee colonies die over winter along with their mites, as it is in warmer climates.
\end{abstract}

Varroa destructor / Apis mellifera / swarming / survival / nordic climate / population dynamics

\section{INTRODUCTION}

At colony level, European honey bees (Apis mellifera L.) reproduce by colony fission (swarming). When honey bees divide by swarming, the first swarm issued normally contains the old laying queen and subsequent swarms, if any, contain unmated queens. Although there is great variation in swarm size, each swarm issued can be expected to part with $50-60 \%$ of the adult bee population (Winston, 1987). There is an age related tendency for younger bees to part with the swarm, although all age categories of bees are represented
(Winston, 1987; Muszynska, 1976). This mode of reproduction by colony fission is ideal for vertical transmission of parasites (between individuals, between generations) to new colonies and probably has consequences for the development of virulence in host-parasite relationships in honey bees under natural conditions (Fries and Camazine, 2001). Beekeepers use different management techniques to regulate swarming because swarming colonies become smaller and produce significantly less honey than non-swarming colonies (Farrar, 1937). Management techniques to prevent swarming include transferring combs between

\footnotetext{
* Correspondence and reprints

E-mail: ingemar.fries@entom.slu.se
} 
colonies, production of daughter colonies (nuclei) with queens that are genetically unrelated to the colonies from which the bees originated, and crowding of bee colonies in apiaries. Such management practices probably alter the mode of parasite transmission in the honey bee system from mainly vertical to mainly horizontal transmission (between individuals within generation).

The parasitic mite Varroa destructor is a relatively new parasite of European honey bees (Anderson and Trueman, 2000). In areas with intense beekeeping, the host-parasite relationship has been molded by evolution only to a limited extent, partly because beekeepers regulate mite populations to avoid damage and collapse of infested colonies. Under Nordic conditions, in colonies managed without mite control, the mite population builds up from an initial low infestation of only a few mites to an infestation of several thousand mites, eventually killing the colonies in 3-4 years (Korpela et al., 1993). However, it is not known how mite population increase and infestation rates are influenced by colony reproduction (swarming). Under natural and managed conditions where swarming and mite populations are not regulated, there are indications that the host parasite relationship becomes more balanced with survival of both host and parasite (Rosenkranz, 1999; de Jong and Gonçalves, 1998; de Jong and Soares, 1997; Boecking and Ritter, 1993). There is some information indicating the mite has made adaptive changes (Milani et al., 1999), but to what extent the development towards a balanced host-parasite relationship is due to adaptive changes in the parasite, in the host, or both is not known. Likewise, there is very little, or no data, demonstrating the influence of swarming on the population increase of the mites and the resulting rate of infestation in swarms and in swarming colonies.

This paper aims to investigate the influence of swarming on the $V$. destructor infestation rate of honey bee colonies and the swarms they issue. The experiment described is part of a study initiated to evaluate if the mites will eradicate European honey bees in an isolated area under Nordic conditions, where no mite control or swarm control of honey bee colonies are implemented.

\section{MATERIALS AND METHODS}

\subsection{Honey bee population and mite infestation background}

We established an isolated honey bee population of 150 colonies in which the mite population build up in unmanaged colonies was monitored for two years. Because of logistic problems and colony losses, the whole test population could not be established simultaneously in the experimental area.

In 1997, 40 mite-free honey bee colonies were moved to Gotland, an island in the Baltic sea, and placed outside the flight range (at least $7 \mathrm{~km}$ ) of other known colonies of bees. The objective was to build up an experimental population of bees from these colonies. This first set of colonies wintered poorly in 1997/1998 and some of these colonies received brood from lightly mite-infested colonies to survive and develop in the spring of 1998. After we made some colony divides, 60 colonies remained in the spring of 1999. From these 60 colonies, nuclei were produced the same year. Thus, in the summer 1999, the 108 colonies in the experiment probably had low levels of mite infestations.

Another 42 mite-free colonies were moved to Gotland in 1999 and all colonies ("old" where some probably had low mite levels, and the "new" mite free colonies) received mites in July 1999. This addition of mites were made by adding $400 \mathrm{~cm}^{3}$ of bees (approximately 1000) directly into each experimental colony. The bees were collected from mite-infested colonies and transported to the experimental sites. Because of the large quantity of bees needed, bees were shaken from infested colonies into four different containers for transport. The mite infestation rate in each container was established to be between 36 and 89 mites based on a separate sub-sample examined from each container.

The genetic composition of the experimental bees was not controlled; upon formation of the nuclei, bees were allowed to rear queens from available brood. The bulk of the bee material from which the nuclei were established, was derived from freely mated, Swedish, undefined Buckfast strains, and from local bees derived from A. m. ligustica. To further broaden the genetic base, 10 queens derived from A. m. carnica and 10 from A. $m$. mellifera were purchased from Swedish bee breeders and introduced into 20 of the 60 colonies that remained in the spring of 1999.

Samples in the fall of 1999 of bees from 15 of the mite-free colonies that were introduced to the island the same year ("new" colonies) and that received 


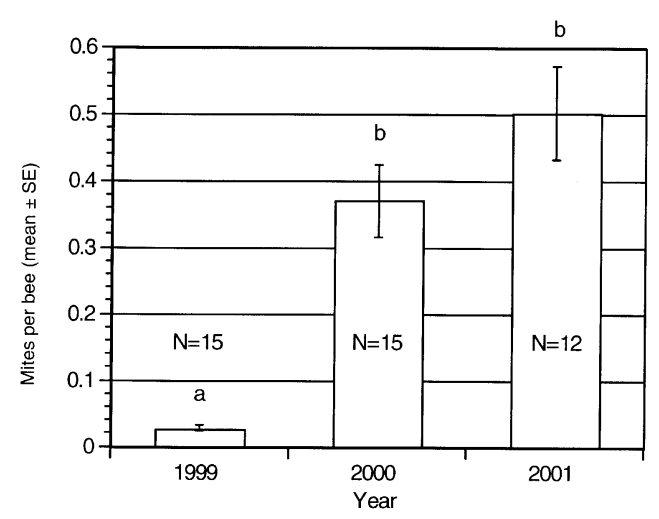

Figure 1. Average number of Varroa destructor per bee in brood-free colonies in October in the only apiary where there was data also from 1999. Bars with different letters are significantly different between years $(P<0.05$, Kruskal-Wallis test).

approximately 36 mites per colony (based on a $400 \mathrm{~cm}^{3}$ sub-sample) confirmed that all colonies were infested (Fig. 1). Thus, 150 lightly miteinfested colonies, placed in eight different apiaries, were wintered in 1999 . The apiaries (N58 $01^{\prime}$ $\mathrm{N} 58^{\circ} 04^{\prime}, \mathrm{E} 18^{\circ} 09^{\prime}-\mathrm{E} 18^{\circ} 15^{\prime}$, only a few meters above sea level) were located on "Sudret", which is the southern tip of the island Gotland in the Baltic Sea, connected to the main island through a narrow land bridge.

From the start of the experiment, all queens were color marked on the thorax. At the first inspection in 2001, all queens were subsequently marked with individual colored numbered tags to enable identification of the origin of first swarms. The only management of experimental colonies consisted of data sampling and of feeding sugar solution before winter in cases where honey stores were deemed insufficient for winter survival.

\subsection{Data collection and analysis}

Mites were counted in colony debris within screened bottom boards on 5 inspections during 2000 and 2002. Period of time between mite counts varied between one week to only one day (the latter only in a few cases) and the average daily mite mortality was calculated for each colony.

Each colony was inspected 4 times during the summer 2000 and 2001 to register if the colonies had swarmed or not. When colonies had emerged queen cells and a break in brood production, they were registered as swarming colonies.
Swarms were collected on site upon inspection, or from swarm boxes put up in the experimental area. The collected swarms were placed in separate apiaries each year.

Late October 2000 and 2001, when colonies had little or no sealed brood in the study region, samples of $100 \mathrm{~cm}^{3}$ of bees were collected from all colonies to measure mite infestation levels. In late October 1999, samples were collected from one apiary only (see results below). Colonies that were wintered each year were regarded as surviving the winter if they had a queen and enough bees to expand (i.e. more than 1000 bees) in June the following year.

Comparisons between mite infestation rates in swarming colonies and non-swarming colonies were made using $\mathrm{t}$-tests within dates and year where appropriate. Kruskal-Wallis tests were used to compare infestation levels in groups of colonies with different histories, followed by multiple comparisons of means among groups (LSD-tests) when significant group effects were present. The data from each year was also analyzed using an ANOVA with "mites per adult bee in October" as a response variable and "swarming" (yes/no) and "presence of late brood" (yes/no) as fixed factors. The data from both years were analyzed together using the same model but with year (year1/year2) added as a fixed factor. To evaluate debris counts of mites vs. infestation rate of mites in brood free colonies, a simple correlation analysis was used.

\section{RESULTS}

\subsection{Swarming vs. non-swarming colonies}

Samples of live bees in October 1999 from the 15 brood-free colonies that were introduced mite-free into the experimental site and that subsequently received approximately 36 mites per colony (the lowest number recorded in a sub-sample) confirmed that all experimental colonies were infested (Fig. 1). The infestation levels of colonies in this apiary (where all colonies swarmed in 2000) were similar in October 2000 and 2001 when compared to the infestation levels in all other experimental colonies (Figs. 1 and 2). Thus, the possible variation in mite infestation rate at the start of the experiment (an undefined low number of mites introduced with brood in 1999 in some colonies and a variation in the number of mites added to each colony) was not considered in the analysis. 


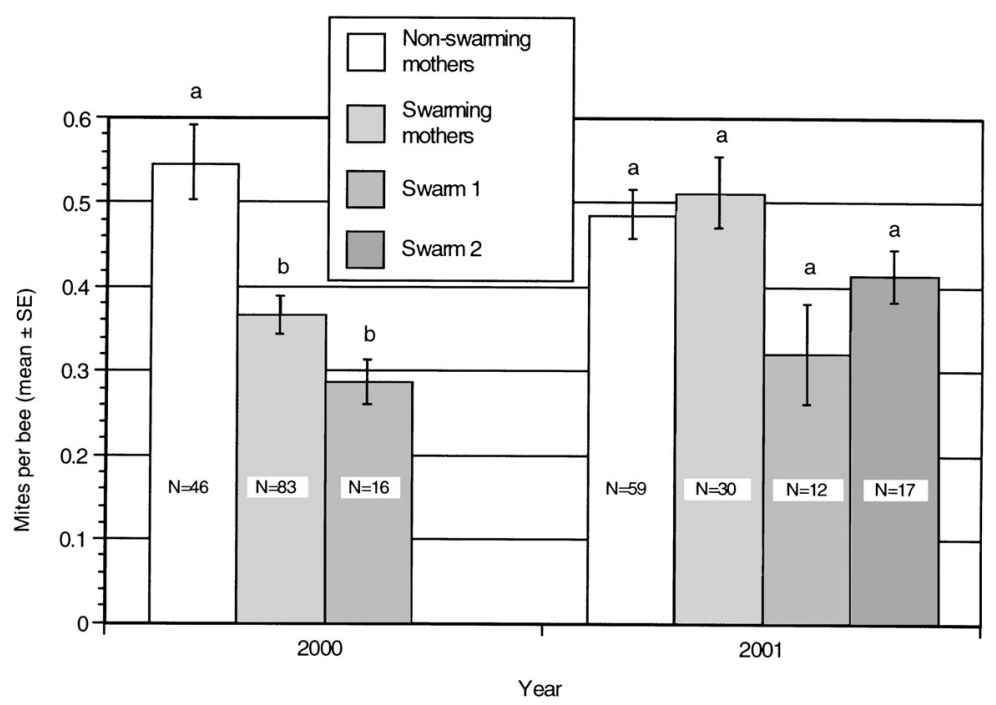

Figure 2. Average number of Varroa destructor per bee in October in swarming (Swarming mothers) and non-swarming colonies (Non-swarming mothers), respectively. The same data is also given for swarms issued in 2000 (swarm 1) and 2001 (swarm 2). Bars with different letters are significantly different within year $(P<0.05, t$-tests for 2000; $P<0.05$, Kruskal-Wallis tests for 2001).

In 2000, there was a significant reduction in the number of mites per bee in late October in swarming colonies when directly compared to non-swarming colonies $(P=0.0001, t$-test $)$. However, the following year, this difference did not persist ( $P=0.344$, $t$-test; Fig. 2$)$.

An analysis of variance using "mites per bee in late October" as dependent variable and "swarming" (yes/no) and "late brood" (yes/no) as factors, did not demonstrate a significant effect of swarming on the mite infestation level for either year $(P=0.097$ and $P=0.242$, respectively). There were no significant interactions between variables. The variable, "late brood rearing" on the other hand, was significant in explaining variation in the response variable both the first $(P<0.0001)$ and the second $(P=0.041)$ year. When the same data was analyzed for both years, including year as a fixed-effect in the model, there was no significant effect of swarming $(P=0.55)$, but late brood was again highly significant $(P<0.0001)$. Also, the year $(P=0.049)$ and the interactions between swarm and year, and between year and late brood were significant $(P=0.041$ and 0.027 respectively) in explaining variations in mite infestations.
In Figure 3, the factor, "mites per adult bee in late October" is divided into four categories: (i) colonies that did not swarm at all, (ii) colonies that did not swarm in 2000 but did swarm in 2001, (iii) colonies that swarmed in 2000 but did not swarm in 2001, and (iv) colonies that swarmed both years. There was no significant difference in the number of mites per adult bee among the four categories in 2001 ( $P=0.33$, Kruskal-Wallis test; Fig. 3).

When the infestation level was monitored using debris counts of mites, significantly fewer mites fell from swarming colonies at all sampling occasions after the swarming season (June) during year 2000 compared to nonswarming colonies $(P<0.05, t$-tests; Fig. 4$)$. This significant difference did not persist through 2001, except for the count on September 7 , when means were compared among swarming colonies, non-swarming colonies, and swarms at each date (Kruskal-Wallis tests; Fig. 4).

\subsection{Swarming colonies vs. swarms}

The swarms issued each year contained fewer mites on average compared to swarming 


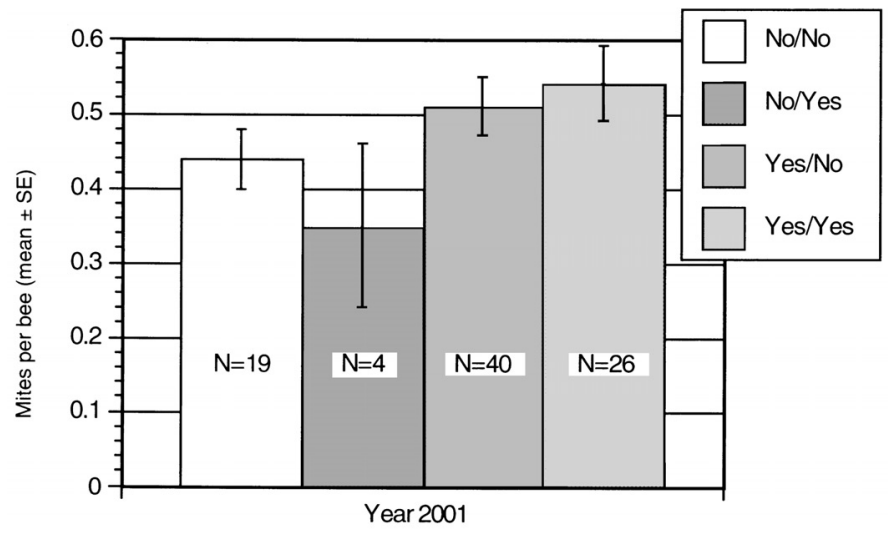

Figure 3. Average number of Varroa destructor per bee in October in colonies that did not swarm in year 2000 or 2001 (No/No), in colonies that did not swarm year 2000 but swarmed 2001 (No/Yes), in colonies that swarmed 2000 but did not swarm 2001 (Yes/No), and in colonies that swarmed both in year 2000 and 2001 (Yes/Yes).

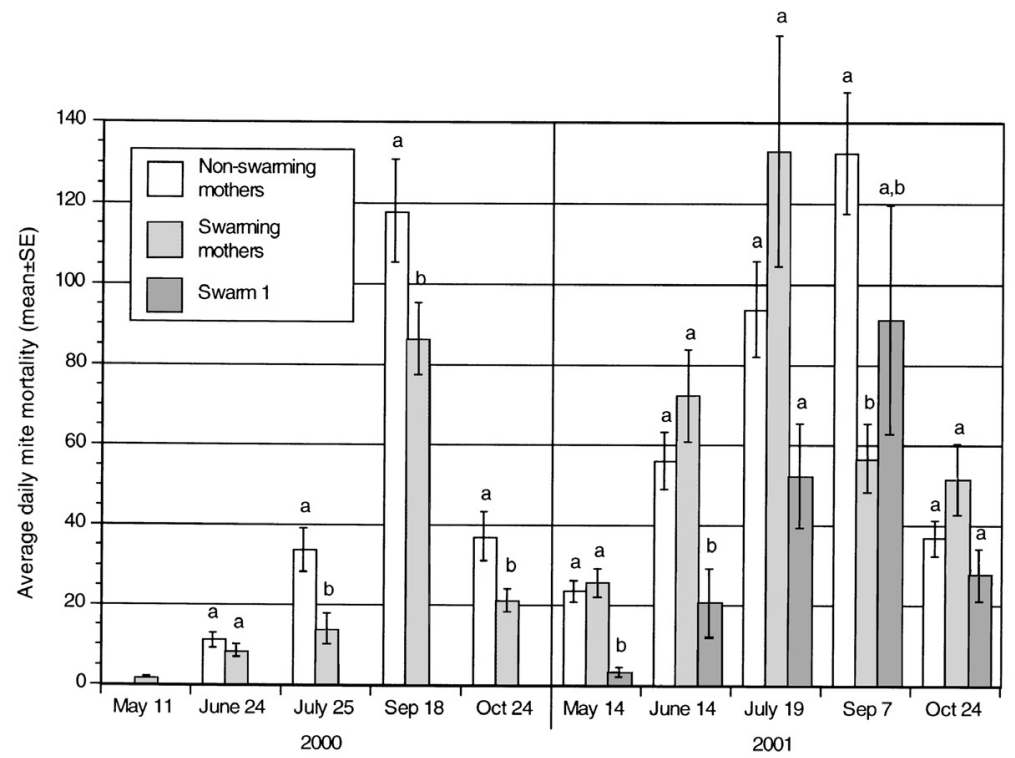

Figure 4. Debris counts (number of dead mites per day) in swarming and non-swarming colonies and in swarms issued 2000 (swarm 1). Bars with different letters are significantly different within date $(P<0.05$, t-test for 2000; $P<0.05$, Kruskal-Wallis tests for 2001). $\mathrm{N}$ for each bar is similar to $\mathrm{N}$ for the corresponding groups in Figure 2.

colonies, but the differences were not statistically significant $(P=0.13$ and 0.14 for each year respectively, $t$-tests; Fig. 2). When both years were analyzed together, however, swarming colonies had significantly higher infestation levels than swarms $(P=0.032)$. The effect of year on infestation rate was also significant $(P=0.001)$ but there was no signif- icant interaction between the variables colony type and year. In the few cases $(\mathrm{N}=8)$ where the swarm origin could be established from the number-marked queens, there was no significant difference in the number of mites per adult bee in late October between the mother colonies and their respective swarms $(P=0.66$, paired $t$-test). The correlation coefficient 
Table I. The number of wintered colonies, number of colonies surviving winter, number of wintered swarms, number of swarms surviving winter each year, and total number of colonies.

\begin{tabular}{lccccc}
\hline Year & Parameter & Original colonies & First year swarms & Second year swarms Total number of colonies \\
\hline 1999 & Wintered & 150 & - & - & 150 \\
2000 & Surviving & 142 & - & - & 142 \\
2000 & Wintered & 130 & 16 & - & 146 \\
2001 & Surviving & 95 & 12 & - & 107 \\
2001 & Wintered & 90 & 11 & 17 & 118 \\
2002 & Surviving & 21 & 6 & 0 & 27 \\
\hline
\end{tabular}

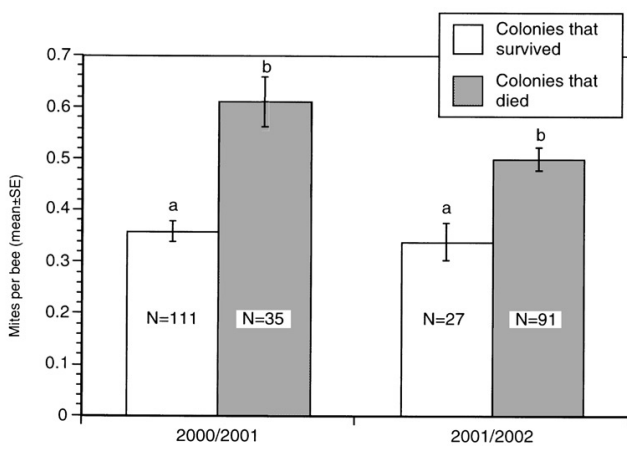

Figure 5. Average infestation rate of adult bees in October in colonies that survived or in colonies that died in the winters $2000 / 2001$ or $2001 / 2002$. Bars with different letters are significantly different within year $(P<0.05$, t-tests $)$.

between mites per adult bee in late October in mother colonies and in their respective swarms was not significant $(\mathrm{r}=-0.35, P=0.41)$.

\subsection{Colony mortality and mite infestation rates}

The number of colonies and swarms that survived winter to the following late May during the experiment are listed in Table I. Colonies lost through drone laying queens were excluded from calculations after this condition was noted. The average mite infestation level of adult bees in the fall for colonies and swarms that survived or died each winter are shown in Figure 5. The infestation level of adult bees in the fall for colonies that survived the winter was significantly lower compared to colonies that died over winter for both years $(P<0.001, t$-test for each year).

\section{DISCUSSION}

\subsection{Swarming vs. non-swarming colonies}

Our results suggest that swarming in honey bee colonies does not prevent the build up of detrimental population levels of $V$. destructor in a Nordic climate. In 2000, colonies that swarmed and the swarms themselves had significantly fewer mites compared to colonies that did not swarm (Fig. 2), but this differences was not maintained the following year, even in colonies issuing swarms both years (Figs. 2 and 3). As colonies swarm, approximately half of the adult bee population leaves the hive, along with the mites they carry. Although as many as $65 \%$ of the mites in brood-producing colonies will be found within sealed brood cells (Martin, 1998), a substantial proportion of adult mites are likely to leave with the first swarm, perhaps 15-20\% based on mite distribution data (Fuchs, 1985; Martin et al., 1998). Furthermore, when bee colonies swarm, there is normally no brood production in the swarming colony for approximately two to three weeks. Without access to brood, there is no mite reproduction for the same period. Nevertheless, in spite of mites leaving with swarms and a cessation of brood rearing in swarming colonies, an effect on mite population build up was only seen in 2000 , but not in 2001. When the whole data set was analyzed, no significant effect of swarming was seen on mite infestation level in the fall. There was a slight significant effect of year, with higher mite levels the second year $(P=0.049)$. There was also a significant interaction between swarming and year 
$(P=0.042)$ with more swarming in 2000 than in 2001 (Tab. I) and between late brood rearing and year $(P=0.027)$ where late brood in heavily infested colonies was more common in 2001. There was no significant interaction between swarming and late brood $(P=0.15)$. The factor that by far explains most of the variation in mite infestation levels in the fall is the production of late brood $(P<0.0001)$. With the presented data it is not possible to determine if late brood rearing produces increased infestation levels in adult bees or if high infestation levels are likely to produce late brood rearing as a compensatory mechanism for mite damages, although we assume the latter to be the case (this is assumed partly because late brood rearing was less common in colonies with young queens - swarming colonies - compared to non-swarming colonies (data not presented)).

We believe that this lack of demonstrated effect from swarming on the mite population build up, particularly in 2001, is due to the interaction between the parasite and its host. High mite counts were reached at a much earlier date in 2001 compared to 2000 (Fig. 4). Although measurements of clinical symptoms were not systematically recorded, it seems likely from debris counts (Fig. 4), that more colonies were damaged from high mite levels in 2001 compared to the year 2000 . It can be hypothesized that some heavily infested colonies during 2001 did not swarm because of damaging effects from the mite, and that the bees were damaged to the extent that mite population growth was limited. Following the same line of thought, the colonies that managed to swarm in 2001 may have been those least damaged by mite infestations, with the best brood production and, thus, with the highest opportunities for mite reproduction, irrespective of the break in brood rearing for two to three weeks. It is obvious from Figure 3 that even if colonies swarmed both during 2000 and 2001, this did not reduce the mite infestation levels in 2001 compared to colonies that did not swarm during any of these two years. Indirectly, these results support the hypothesis that the mite population growth in non-swarming colonies may have been more limited by host-parasite interactions, compared to swarming colonies.

\subsection{Swarming colonies vs. swarms}

Although there was a trend in both 2000 and 2001 that fewer mites were found in the swarms compared to the swarming colonies, this difference was not significant either year. When the two years were analyzed together, however, it could be demonstrated that swarming colonies, on average, have fewer mites in late fall compared to swarms issued the same year. In the few cases where it was possible to identify the origin of the swarm and make paired comparisons between swarming colonies and their respective first swarm $(\mathrm{N}=8)$, there was no significant difference in mite infestation levels of adult bees in the fall. Generally, this indicates that swarms in a Nordic climate only have marginally better chances if any, to avoid being damaged by mite infestations compared to the colonies that issued them.

\subsection{Colony mortality and mite infestation rates}

As could be expected, the effect of mite infestation level on colony mortality over winter is evident, but it is also clear that some colonies survived winter with substantial mite infestations (Fig. 5). Not a single colony in the present experiment was lost due to robbing by stronger colonies. Colonies died from failure to survive the winter (Fig. 5) or from loss due to drone-laying or failing queens. This distinction is important, because horizontal mite transfer by robbing from highly infested colonies contributes to difficulties in mite control in warmer climates (Greatti et al., 1992; Sakofski, 1989). Our data suggest that under Nordic climatic conditions, most colonies that die due to mite infestations (or associated conditions) will be lost during winter, and, consequently, their mites die along with them. This implies that vertical transmission of mites between colonies through swarming could be more dominant in cold climates compared to warmer climates, which again may influence mite virulence in unmanaged honey bee populations (Fries and Camazine, 2001).

To some extent, we are surprised by the limited effect of swarming on mite population development. We hypothesize that as the mite population builds up, the host-parasite interaction becomes important in regulating the 
further development of the mite population and, thus, in masking the effect of swarming at lower infestation levels. To better understand the host-parasite interactions before colony break down from mite infestations, brood production and adult bee populations in infested colonies must be monitored much more closely than was done in our experiment. The prevalence of different viruses associated with $V$. destructor (Allen and Ball, 1996) was not monitored in this investigation. This aspect may also warrant further studies to understand colony collapse associated with high mite infestation levels (Martin et al., 1998). Nevertheless, the final conclusion remains: swarming may significantly reduce mite levels in swarming colonies where the host-parasite interaction is limited, but does not prevent detrimental mite levels from developing under Nordic conditions in swarming colonies, or in their swarms. As mite levels increase to detrimental levels in the colonies, mite population growth is negatively affected and may also deter colonies from swarming by the negative effects on the bee population. If heavily infested colonies are able to swarm, this probably reduces the mite population, but they reach mite levels similar to non-swarming colonies, presumably because swarming colonies allow mites a better environment for reproduction, thus masking the effect of swarming on the mite population.

Further observations will document if the population of honey bees studied will be eradicated due to the mite infestations.

\section{ACKNOWLEDGEMENTS}

The dedicated efforts from beekeeper Åke Lyberg in supplying infrastructure and ground support is highly appreciated. The study had financial support from the National Board of Agriculture through the European Commission supported "National programme for support of beekeeping and sale of honey", from the "Gesellschaft der Freunde der Landesanstalt für Bienenkunde an der Universität Hohenheim e.V.", and from the Swiss Beekeepers Association, which is highly appreciated.

Résumé - Influence de l'essaimage sur le développement des populations d'abeilles domestiques (Apis mellifera) et de l'acarien Varroa destructor en Suède. Au sein d'une population d'abeilles domestiques, le développement d'une population d'acariens Varroa destructor introduits a été suivie dans des colonies essaimantes et des colonies non essaimantes durant deux années en conditions de climat nordique. L'étude visait à étudier l'influence de l'essaimage sur le taux d'infestation des abeilles par l'acarien et sur les essaims qui en étaient issus. Les données suivantes, comptage des débris d'acariens et récolte des abeilles vivantes à la fin de l'automne dans la plupart des colonies sans couvain, ont été collectées afin de déterminer le taux d'infestation et de noter l'état de l'essaim. Nos résultats montrent que l'essaimage chez les colonies d'abeilles n'empêche pas, sous climat nordique, le développement des populations de $V$. destructor.

Les essaims produits chaque année renfermaient en moyenne moins d'acariens que les colonies essaimantes de la fin de l'automne, mais les différences ne sont pas statistiquement significatives si l'on prend en compte la présence ou l'absence d'élevage tardif de couvain. Dans les quelques cas où l'origine de l'essaim a pu être établi d'après la pastille numérotée des reines $(\mathrm{N}=8)$, le nombre d'acariens par abeilles adultes à la fin d'octobre n'est pas significativement différent entre les colonies mères et leurs essaims respectifs. Le niveau d'infestation des essaims à la fin de l'automne n'est pas significativement différent de celui des colonies essaimantes, à moins d'analyser les deux années ensemble ; ceci indique que la survie de l'essaim peut être affectée par l'acarien presqu'autant que celle des colonies essaimantes intactes. Bien qu'il y ait une diminution significative des débris d'acariens (Fig. 3) aussi bien que du taux d'infestation des abeilles adultes à l'automne 2000 (Fig. 2), ces différences ne se sont pas renouvelées l'année suivante, même chez les colonies ayant produit des essaims les deux années (Figs. 2 et 3). Les résultas suggèrent en outre que sous climat nordique, où les colonies d'abeilles parasitées par $V$. destructor meurent principalement au cours de l'hiver avec leurs acariens, le transfert horizontal par le pillage peut jouer un rôle moindre que celui qui a été mis en évidence dans les zones climatiques plus chaudes.

Varroa destructor / Apis mellifera / essaimage / survie / climat nordique / dynamique des populations

Zusammenfassung - Schwarmverhalten bei Honigbienen (Apis mellifera) und die Entwicklung der Population von der Varroa Milbe (Varroa destructor) in Schweden. Bei einer Population von 150 Honigbienenvölkern wurde die Entwicklung der Population von zugefügten Varroa Milben in schwärmenden und nicht schwärmenden Völkern überprüft. Der Versuch wurde zwei Jahre lang unter nordischen Klimabedingungen durchgeführt. Dabei wurde der Einfluss des Schwärmens auf die Befallsrate mit $V$. destructor gemessen und ihre Erzeugung von Schwärmen beobachtet. Die 
Erfassung der Daten beinhaltete die Zählung der Milben im Milbentotenfall, das Sammeln von lebenden Bienen im Spätherbst in fast brutfreien Völkern zur Bestimmung der Befallsrate und die Registrierung des Zustandes des Schwarms. Unsere Ergebnisse zeigten, dass das Schwärmen der Völker einen Aufbau einer schädigenden Milbenpopulation im nordischen Klima nicht verhinderte. Die jedes Jahr erzeugten Schwärme enthielten im Spätherbst zwar im Schnitt weniger Milben als die schwärmenden Völker, aber die Unterschiede waren nicht signifikant, berücksichtigt wurde ob eine späte Brutaufzucht stattfand. In einigen Fällen, in denen das Ursprungsvolk des Schwarms durch die mit einer Nummer gezeichneten Königin bestimmt werden konnte $(\mathrm{N}=8)$, ergab sich im späten Oktober kein signifikanter Unterschied zwischen Muttervolk und dessen Schwarm in Bezug auf Anzahl der Milben pro Biene. Das Niveau des Milbenbefalls der Schwärme war im Spätherbst nicht signifikant unterschiedlich zwischen Schwärmen und schwärmenden Völkern, außer wenn beide Jahre zusammen analysiert wurden. Das könnte bedeuten, dass das Überleben der Schwärme vielleicht genau so von der Varroa Milbe beeinflusst wird, wie das der intakten schwärmenden Völker. Obwohl es im Jahr 2000 eine signifikante Abnahme der von Schwärmen abgefallenen Milben (Abb. 3) sowie in der Befallsrate von adulten Biene gab (Abb. 2), traten diese Unterschiede im folgenden Jahr nicht wieder auf, auch nicht in Völkern, die in beiden Jahren Schwärme erzeugten (Abb. 2, 3). Diese Ergebnisse lassen ebenfalls darauf schließen, dass in nordischen Klimazonen, in denen die durch Varroa destructor geschädigten Völker der Honigbienen vor allem über Winter zusammen mit ihren Milben sterben, ein horizontaler Milbeneintrag durch Räuberbienen eine geringere Rolle spielt als dies für wärmere Klimazonen nachgewiesen wurde.

\section{Varroa destructor / Apis mellifera / Schwärmen / Überleben / nordische Klimabedingungen}

\section{REFERENCES}

Allen M., Ball B. (1996) The incidence and world distribution of honey bee viruses, Bee World 77 , 141-162.

Anderson D.L., Trueman J.W.H. (2000) Varroa jacobsoni (Acari: Varroidae) is more than one species, Exp. Appl. Acarol. 24, 165-189.
Boecking O., Ritter W. (1993) Grooming and removal behaviour of Apis mellifera intermissa in Tunisia against Varroa jacobsoni, J. Apic. Res. 32, 127 134.

De Jong D., Gonçalves L.S. (1998) The Africanized bees of Brazil have become tolerant to Varroa, Apiacta 33, 65-70.

De Jong D., Soares A.E.E. (1997) An isolated population of Italian bees that has survived Varroa jacobsoni infestation without treatment for over 12 years, Am. Bee J. 137, 742-745.

Farrar C.L. (1937) The influence of colony populations on honey production, J. Agric. Res. 54, 945-954.

Fries I., Camazine S. (2001) Implications of horizontal and vertical pathogen transmission for honey bee epidemiology, Apidologie 32, 199 214.

Fuchs S. (1985) Untersuchungen zur quantitativen Abschätzung des Befalls von Bienenvölkern mit Varroa jacobsoni Oudemans und zur Verteilung des Parasiten im Bienenvolk, Apidologie 16, 343-368.

Greatti M., Milani N., Nazzi N. (1992) Reinfestation of an acaricide-treated apiary by Varroa jacobsoni Oud., Exp. Appl. Acarol. 16, 279-286.

Korpela S., Aarhus A., Fries I., Hansen H. (1993) Varroa jacobsoni Oud. in cold climates: population growth, winter mortality and influence on survival of honey bee colonies, J. Apic. Res. 31, 157-164.

Martin S.A., Hogarth A., van Breda J., Perrett J. (1998) A scientific note on Varroa jacobsoni Oudemans and the collaps of Apis mellifera L. colonies in the United Kingdom, Apidologie 29, 369-370.

Milani N., Pechhacker H., Della Vedova G. (1999) Reduced fertility in European population of Varroa jacobsoni Oud., Apidologie 30, 435-436.

Muszynska J. (1976) Porównanie pszczól z roju macierzaka, Pszczel. Zesz. Nauk. 20, 191-201.

Rosenkranz P. (1999) Honey bee (Apis mellifera L.) tolerance to Varroa jacobsoni Oud. in South America, Apidologie 30, 159-172.

Sakofski F. (1989) Transfer of Varroa jacobsoni by robbing, in: Cavalloro R. (Ed.), Present status of varroatosis in Europe and progress in the varroa mite control, Luxemburg, Commission of the European Communities, pp. 177-181.

Winston (1987) The biology of the honey bee, Harvard University Press, London, UK. 